\title{
Somatostatin receptor expression in parathyroid neoplasms
}

\author{
Sara StorvalI ${ }^{1}$, Helena Leijon², Eeva Ryhänen ${ }^{1}$, Johanna Louhimo ${ }^{3}$, Caj Haglund ${ }^{3}$, Camilla Schalin-Jäntti ${ }^{1}$ and \\ Johanna Arola ${ }^{2}$
}

${ }^{1}$ Department of Endocrinology, Abdominal Center, University of Helsinki and Helsinki University Hospital, Helsinki, Finland

2Department of Pathology and Huslab, University of Helsinki and Helsinki University Hospital, Helsinki, Finland

${ }^{3}$ Department of Surgery, University of Helsinki and Helsinki University Hospital, Helsinki, Finland

Correspondence should be addressed to J Arola: johanna.arola@hus.fi

\begin{abstract}
Introduction: Parathyroid carcinoma represents a rare cause of primary hyperparathyroidism. Distinguishing carcinoma from the benign tumors underlying primary hyperparathyroidism remains challenging. The diagnostic criteria for parathyroid carcinoma are local and/or metastatic spreading. Atypical parathyroid adenomas share other histological features with carcinomas but lack invasive growth. Somatostatin receptors are commonly expressed in different neuroendocrine tumors, but whether this also holds for parathyroid tumors remains unknown.

Aim: Our aim is to examine the immunohistochemical expression of somatostatin receptor 1-5 in parathyroid typical adenomas, atypical adenomas and carcinomas. Methods: We used a tissue microarray construct from a nationwide cohort of parathyroid carcinomas ( $n=32)$, age- and gender-matched typical parathyroid adenomas $(n=72)$ and atypical parathyroid adenomas $(n=27)$ for immunohistochemistry of somatostatin receptor subtypes 1-5. We separately assessed cytoplasmic, membrane and nuclear expression and also investigated the associations with histological, biochemical and clinical characteristics.

Results: All parathyroid tumor subgroups expressed somatostatin receptors, although membrane expression appeared negligible. Except for somatostatin receptor 1, expression patterns differed between the three tumor types. Adenomas exhibited the weakest and carcinomas the strongest expression of somatostatin receptor 2, 3, 4 and 5. We observed the largest difference for cytoplasmic somatostatin receptor 5 expression. Conclusions: Parathyroid adenomas, atypical adenomas and carcinomas all express somatostatin receptor subtypes 1-5. Somatostatin receptor 5 may serve as a potential tumor marker for malignancy. Studies exploring the role of somatostatin receptor imaging and receptor-specific therapies in patients with parathyroid carcinomas are needed.
\end{abstract}

\section{Key Words}

- parathyroid

- cancer

- somatostatin

- immunohistochemistry

- hyperparathyroidism

- tumor

\section{Introduction}

Primary hyperparathyroidism (PHPT) is a common endocrine disease usually caused by a parathyroid adenoma (in $85 \%$ of cases) or by glandular hyperplasia (15\% of cases). Parathyroid carcinoma is only rarely the underlying cause (PC; about $\sim 1 \%$ of PHPT). Symptoms of PC are related to the high serum calcium caused by the increased parathormone production and are the same but often more severe than those accompanying benign forms of PHPT. Furthermore, PC is very rare and difficult to diagnose, with no specific evidence-based treatment available (1, 2, 3, 4). Radical surgery is the only known potential cure for PC, while recurrence affects $20-60 \%$ of

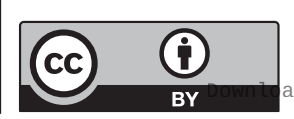

This work is licensed under a Creative Commons Attribution 4.0 International License. 
patients $(5,6,7,8)$. Furthermore, recent studies reported an increasing incidence of PC in Australia, the USA and Europe $(8,9,10)$, although the reasons for this increase remain unknown. The diagnostic criteria of PC are based on histological examination demonstrating invasive tumor growth or evidence of metastatic disease (11). Similarly, atypical adenomas (APAs) share some histopathological features with PC, such as a fibrous septae and intratumoral hemorrhage, although lacking invasive growth (11). Biochemically severe PHPT might raise the suspicion of malignant disease before surgery. However, there are no disease-specific preoperative markers for $\mathrm{PC}$, and it is nearly impossible to render a preoperative diagnosis of PC if the patient has no signs of metastatic disease. Some immunohistochemical markers indicating aggressive tumor behavior in PC and APA exist, such as a high Ki-67 percentage $(>5 \%)(2,12)$. A negative parafibromin stain is present in up to $75 \%$ of sporadic PCs, but rarely in adenomas $(13,14)$. Parafibromin is encoded by $C D C 73$, a tumor suppressor gene. Germline mutations of $C D C 73$ lead to the loss of parafibromin expression and are associated with a high risk of PC $(15,16)$. CDC73 germline mutations underlie the hyperparathyroidism jaw-tumor syndrome (HPT-JT), characterized by early-onset PHPT, ossifying jaw fibromas, kidney and uterine tumors, but may also cause familial isolated hyperparathyroidism $(15,16,17)$. Parafibromin immunohistochemistry is thus a useful marker. The specificity of negative staining is high (18) and prompts genetic studies, that is search for CDC73 germline mutations and genetic counseling, as appropriate. However, there are exceptions and more than $20 \%$ of PC cases stain positive for parafibromin on immunohistochemistry.

Somatostatin receptors (SSTs) mediate the effects of the hormone somatostatin. These membrane-bound G-protein-coupled receptors mediate their effects by altering the levels of intracellular calcium and cAMP. They may also heterodimerize with each other, as well as with $\beta$-adrenergic and opioid receptors, which, depending on the receptor type, can inhibit or enhance the effects of SST. There are five known SST subtypes: $\mathrm{SST}_{1}, \mathrm{SST}_{2}$, $\mathrm{SST}_{3}, \mathrm{SST}_{4}$ and $\mathrm{SST}_{5}$. Through alternative splicing, two variants of $\operatorname{SST}_{2}\left(\mathrm{SST}_{2} \mathrm{a}\right.$ and $\left.\mathrm{SST}_{2} \mathrm{~b}\right)$ exist. Moreover, SSTs can be found throughout the body with differing subtype distributions in various organs and tissues: in the central nervous system, the gastrointestinal tract, the pancreas and the kidneys as well as in leukocytes, endothelial cells and macrophages (19).

Somatostatin analogs are widely used in the treatment of different neuroendocrine tumors, such as
ACTH-producing pituitary adenomas, somatotropinomas and gastropancreatic neuroendocrine neoplasms. They not only suppress hormonal hypersecretion by binding to different SSTs, but also have an antiproliferative effect on tumor cells (20). The somatostatin analog octreotide as well as peptide receptor-based radiotherapy, both of which primarily target $\mathrm{SST}_{2}$, have been used in the treatment of PTH-related protein (PTHrP)-dependent hypercalcemia caused by metastatic gastroenteropancreatic neuroendocrine tumors. As such, diminished calcium and PTHrP concentrations as well as stable disease were achieved in some patients (21). A previous study found somatostatin receptors 1,3 and 4 expression in normal parathyroid cells (22). No previous studies on the expression of SSTs in neoplastic parathyroid tissue appear in the literature.

Therefore, we aimed to investigate the expression profile of somatostatin receptor subtypes in different parathyroid tumors underlying PHPT in a large patient cohort. We also sought to determine whether SSTs could serve as tumor markers in the differential diagnosis of typical parathyroid adenomas, atypical adenomas and carcinomas, perhaps as additive PC immunohistochemistry panel markers to the previously established parafibromin, Ki-67, galectin 3 and protein gene product 9.5 (PGP9.5) (15).

\section{Materials and methods}

\section{Tumor material and patient cohort}

Our material comprised 132 tumor samples from three tissue subgroups: parathyroid carcinomas (PCs), atypical parathyroid adenomas (APAs) and parathyroid adenomas (PAs).

The PC group consisted of tissue specimens from all patients diagnosed with PC in Finland between 2000 and $2011(n=32)(8)$. The PC patients were identified from the Finnish Cancer Registry using the ICD-10 code (C75.0) and from the databases of the five Finnish university hospitals and eight Finnish central hospitals, including their pathology databases.

Both the APA patients $(n=27)$ and the PA patients $(n=72)$ were retrieved from the Helsinki University Hospital pathology database (HUSLAB). The APA group $(n=27)$ consisted of a consecutive cohort diagnosed between 2000 and 2011. The PA patients were age and gender matched with the PC group. All PHPT patients with APAs and PAs were treated in the Endocrine Department at the Helsinki University Hospital.

This work is licensed under a Creative Commons Attribution 4.0 International License. ded from Bioscientifica.com at 04/26/2023 05:02:46AM 
Table 1 Characteristics of patients with parathyroid carcinoma. Numbers are presented as median (range).

Number of patients

Age at diagnosis (years)

Preoperative serum ionized calcium $(\mathrm{mmol} / \mathrm{L})$

Preoperative PTH (ng/L)

Ki-67\%

Patients with metastatic disease or local recurrence

Disease-related death

Clinical data as well as the basic immunohistochemical characteristics of the tumors were described previously (8). Briefly, six PC patients had metastatic disease and two had local recurrence. None of the patients had MEN1. More information on the PC group appears in Table 1.

The Ethics Committee of Helsinki University Hospital approved the study protocol. Permission to use the histological specimens for this study without requiring individual informed consent was granted by the Finnish National Supervisory Authority for Welfare and Health (Valvira) (Dnro 8031/06.01.03.01/2015).

\section{Tissue microarray}

The tissue microarray (TMA) blocks were created as described previously. Briefly, the most representative tumor blocks were chosen and six $1.0 \mathrm{~mm}$ cores from PC and APA samples, and three cores for PAs were punched for the TMA blocks, representing both the tumor border and central areas (8).

\section{Immunohistochemistry}

Tissue sections $(3.5 \mu \mathrm{m})$ were cut using a microtome. Heat-induced antigen retrieval was performed after deparaffinization using xylene and graded alcohol series. Sections were incubated using primary antibodies. Table 2 summarizes information on the antibodies used as well as the staining details. These antibodies have previously been used by our research group also including negative controls (23), and their specificity have been confirmed by Western blot and in vitro receptor autoradiography $(24,25,26,27,28)$. Antibody binding was visualized using the polymer-based OptiView and UltraView Universal DAB Detection Kit (Ventana Medical System, Inc., Tucson, AZ, USA) or the EnVision Detection Systems (Dako, Agilent Pathology Solutions). Automated (Benchmark Ultra, Ventana) or semi-automated (AutoStainer, Lab Vision Corp., Fremont, CA, USA) staining instruments were used. Mayer's hematoxylin (Dako) was used for the counterstaining on all slides. In addition, intestinal mucosa and Langerhans' islet cells were used as positive controls. Normal parathyroid tissue was stained using SST antibodies for comparison.

\section{Scoring}

The immunohistochemical scoring was done independently by two researchers (SS and HL), without knowledge of the nature of the tumors. For any disagreements, the score was determined by reaching consensus following a discussion of the case. Staining was assessed separately for cytoplasmic (C), nuclear (N) and membranous (M) staining. Examples of representative SST stainings appear in Fig. 1. Staining was considered positive if at least $1 \%$ of the tumor cells per spot was stained. The intensity of the staining was estimated using a score of 0 to 3 , where 0 represented completely negative and 3 represented as intense staining as in the positive control tissue. For each tumor, the TMA spot with the strongest staining intensity was used in the statistical analyses. Overall, the staining intensity was weak, and the intensity was not taken into account in the primary analyses, that is, TMA spots were only considered positive or negative. Scoring was carried out using $10 \times$ and 20× magnification for $\mathrm{SST}_{2}, \mathrm{SST}_{3}$ and $\mathrm{SST}_{4}$. The slides stained with antibodies for $\mathrm{SST}_{1}$ and $\mathrm{SST}_{5}$ were digitized using a panoramic scanner (3DHISTECH) and scoring was performed on digitized slides using the CaseViewer software (3DHISTECH), also relying on $10 \times$ and $20 \times$ magnifications.

Table 2 Antibodies and staining protocols used.

\begin{tabular}{|c|c|c|}
\hline Receptor & Clone & Epitope sequence \\
\hline SSTR1 & UMB-7 & ENLESGGVFRNGTCTSRITTL \\
\hline SSTR2 & UMB-1 & ETQRTLLNGDLQTSI \\
\hline SSTR3 & UMB-5 & QLLPQEASTGEKSSTMRISYL \\
\hline SSTR4 & Sstr4 & CQQEALQPEPGRKRIPLT \\
\hline SSTR5 & UMB-4 & QEATPPAHRAAANGLMQTSKL \\
\hline
\end{tabular}

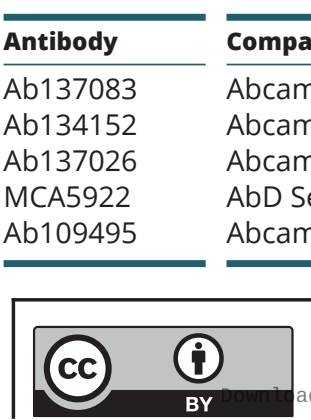

\begin{tabular}{l} 
Company \\
\hline Abcam \\
Abcam \\
Abcam \\
AbD Serotec \\
Abcam
\end{tabular}

\begin{tabular}{lll}
\hline Dilution & Dilution time \\
\cline { 1 - 1 } $1: 500$ & & $45 \mathrm{~min}$ \\
$1: 300$ & $32 \mathrm{~min}$ \\
$1: 7000$ & & $60 \mathrm{~min}$ \\
$1: 500$ & $30 \mathrm{~min}$ \\
$1: 1000$ & $30 \mathrm{~min}$ \\
\hline
\end{tabular}


0.

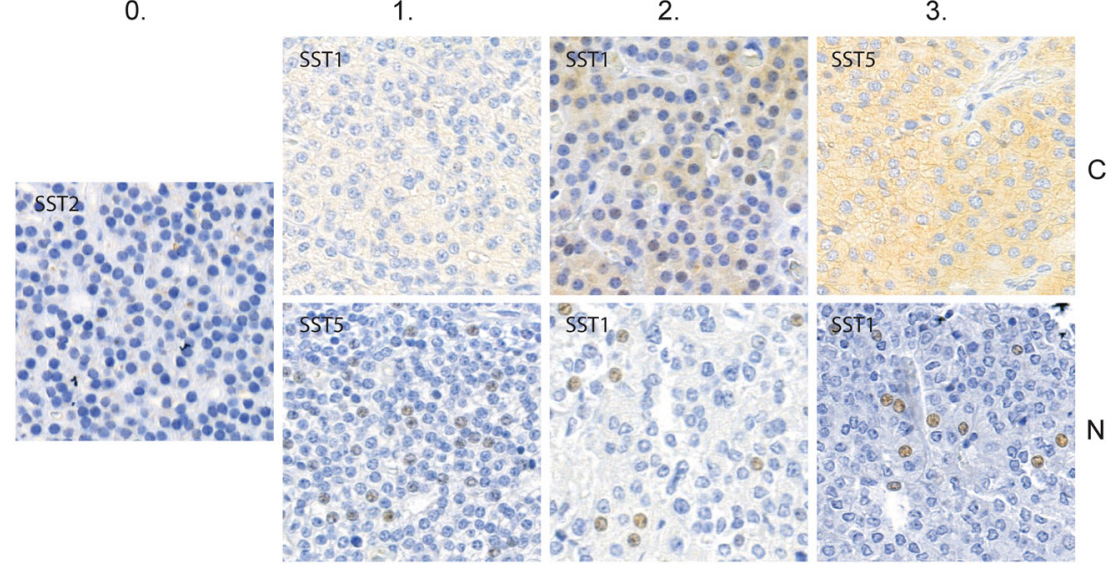

C

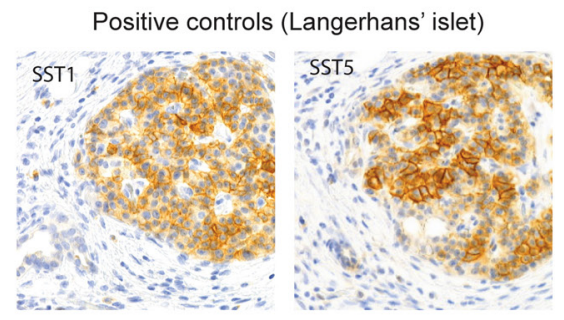

\section{Figure 1}

Examples of the staining intensities in parathyroid tumor tissue for the scoring system used in our study for cytoplasmic and nuclear expression. Membrane expression was weak and the intensity was not sufficiently diverse to make a similar comparison. Left: negative staining (0). Subsequent: weak cytoplasmic and nuclear staining (1), strong cytoplasmic and nuclear staining (2) and very strong cytoplasmic and nuclear staining (3). On the right are pancreatic islets stained with SST1 and SST5 presenting cytoplasmic and membrane positivity, functioning as positive control. Nuclear positivity is not found in the control stainings.

\section{Statistical analysis}

We used IBM SPSS Statistics version 23 (SPSS, Inc.) and RStudio version 1.0.153 (RStudio, Inc.) software for all statistical analyses and data processing. We considered $P<0.05$ (two-tailed) as statistically significant. We used the $\chi^{2}$ test and the Fisher's exact test, as appropriate, to investigate the relationships between categorical parameters. The Mann-Whitney $U$ test was used for continuous variables.

\section{Results}

All SST subtypes were to some degree expressed in parathyroid tumors. Normal parathyroid tissue $(n=6)$ was negative, except for some weak, diffuse cytoplasmic $\mathrm{SST}_{5}$ staining in four of six tissue samples. Cytoplasmic SST and $\mathrm{SST}_{5}$ were the most abundantly expressed SST subtypes in parathyroid tumors. Yet, membrane expression was negligible in all receptor subtypes and was, therefore, excluded from comparisons. Individual tumors, however, were of particular interest. Detailed information regarding SST expression appears in Fig. 2 and Table 3.

\section{Somatostatin receptor $1\left(\mathrm{SST}_{1}\right)$}

Membrane expression was absent for all tumor subtypes. Yet, both nuclear and cytoplasmic expression of SST Sas $_{1}$ present, although expression did not differ significantly between the three tumor subgroups.

\section{Somatostatin receptor $2\left(\mathrm{SST}_{2}\right)$}

Cytoplasmic staining was most prevalent in carcinomas and less so in APA and PA $(P=0.01)$. However, staining was scarce for all tumor subtypes. Interestingly, membrane positivity was found in only two carcinomas.

\section{Somatostatin receptor $3\left(\mathrm{SST}_{3}\right)$}

Cytoplasmic expression was weak and did not differ between the tumor subgroups. As with $\mathrm{SST}_{2}$, we found two $\mathrm{SST}_{3}$ membrane-positive carcinomas. These were not the same tumors that demonstrated $\mathrm{SST}_{2}$ membrane positivity. The nuclear expression of $\mathrm{SST}_{3}$ in the PC group was increased, compared to the expression in the APA and PA subgroups $(P<0.001)$.

\section{Somatostatin receptor $4\left(\mathrm{SST}_{4}\right)$}

Both cytoplasmic and nuclear expression increased in PC compared to the other tumor groups (cytoplasmic $P=0.032$; nuclear $P=0.009$ ). Membranous expression occurred in a small number of tumors across all tumor subgroups, although the difference between groups was not significant.

\section{Somatostatin receptor $5\left(\mathrm{SST}_{5}\right)$}

The largest difference between groups was found in the expression of $\mathrm{SST}_{5}$. The cytoplasmic expression of $\mathrm{SST}_{5}$ appeared weakest in PAs, intermediate in APAs and highest in PC, since nearly all carcinomas were positive $(P<0.001)$. The positive predictive value (PPV) of positive cytoplasmic

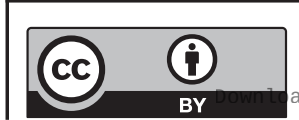

This work is licensed under a Creative Commons Attribution 4.0 International License. ded from Bioscientifica.com at 04/26/2023 05:02:46AM 

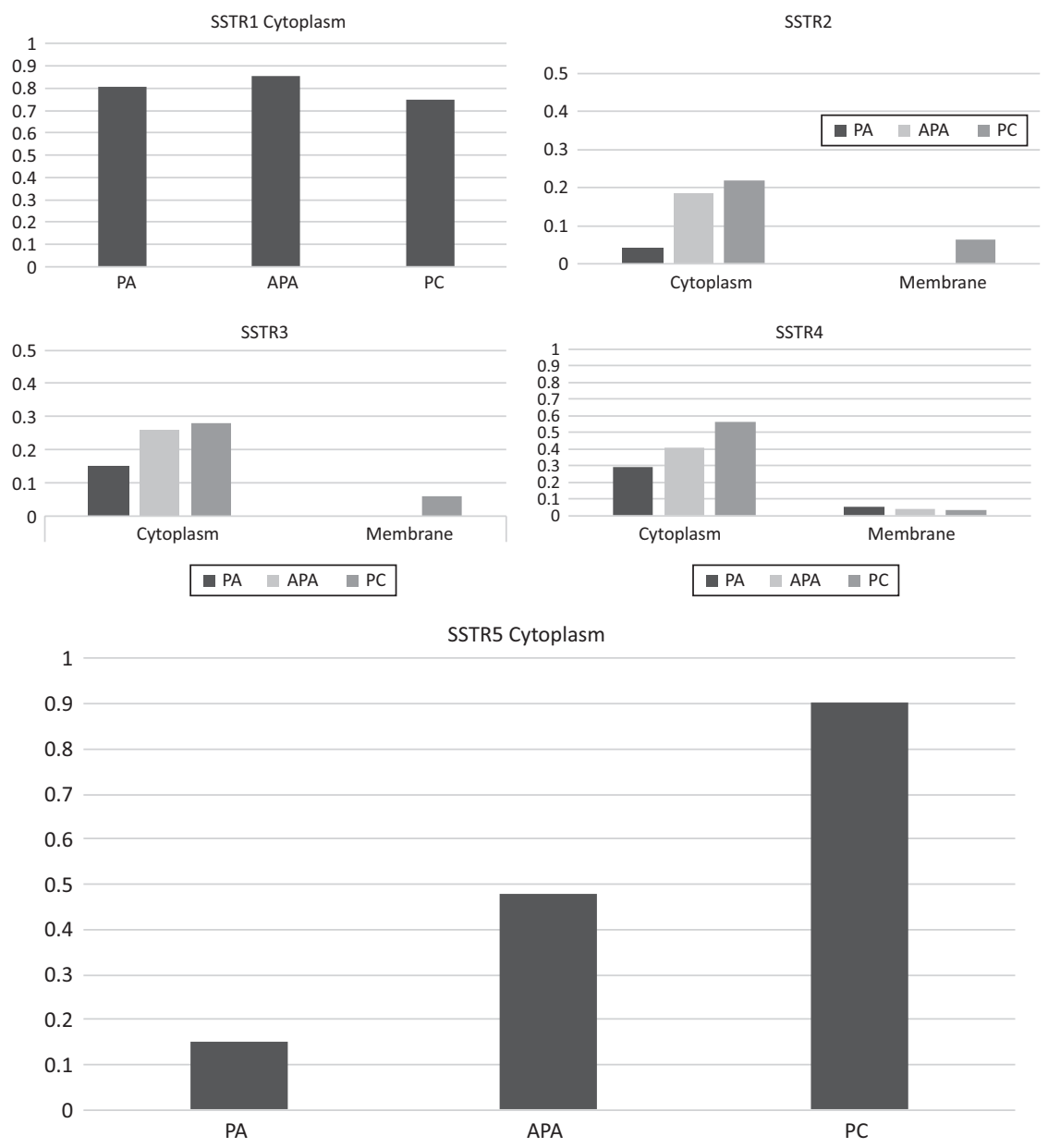

Figure 2

Distribution of the cytoplasmic and membranous SSTs in parathyroid carcinoma (PC), atypical parathyroid adenoma (APA) and benign parathyroid adenoma (PA). The $Y$ axis represents the proportion of positively stained TMA spots.
$\mathrm{SST}_{5}$ staining is 0.52 , while the negative predictive value (NPV) of $\mathrm{SST}_{5}$ staining is 0.94 . Furthermore, the nuclear expression differed significantly between subgroups $(P=0.043)$. Membrane $\mathrm{SST}_{5}$ staining was negative.

\section{Association with other parameters}

Table 4 summarizes the correlations between SST expression and other biomarkers. Only three of our PC tumors had negative parafibromin staining, and another 12 had diminished staining. Negative parafibromin staining was associated with cytoplasmic $\mathrm{SST}_{2}(P=0.04)$ and nuclear $\mathrm{SST}_{3}$ $(P=0.019)$ positivity. There was no association between expression of parafibromin and $\mathrm{SST}_{5}(P=0.192)$.

A higher Ki-67 level was associated with the positive expression of cytoplasmic $\mathrm{SST}_{4}(P=0.048)$ and $\mathrm{SST}_{5}$ $(P<0.001)$ as well as the nuclear expression of $\mathrm{SST}_{3}$ and $\mathrm{SST}_{5}(P=0.003$ and $P<0.001$, respectively). Tumor size was not related to the expression of any of SST subtypes. Yet, high preoperative serum-ionized calcium and PTH concentrations were both associated with the expression of cytoplasmic $\mathrm{SST}_{5}(P<0.001$ for both).

\section{The role of somatostatin receptors in PCs}

The expressions of $\mathrm{SST}_{5}, \mathrm{SST}_{2} \mathrm{M}$ and $\mathrm{SST}_{3} \mathrm{M}$ were examined in carcinomas exclusively. The expression patterns in relation to disease aggressiveness appear in Table 5.

We found that $\mathrm{SST}_{5} \mathrm{C}$-negative carcinomas $(n=3)$ may be more aggressive than $\mathrm{SST}_{5} \mathrm{C}$-positive carcinomas. One SST $_{5} \mathrm{C}$-negative PC patient died of disease,

Table 3 Tumors staining positive for SSTR.

\begin{tabular}{l} 
Receptor \\
\hline SSTR1 C \\
SSTR1 N \\
SSTR2 C \\
SSTR2 M \\
SSTR3 C \\
SSTR3 N \\
SSTR3 M \\
SSTR4 C \\
SSTR4 N \\
SSTR4 M \\
SSTR5 C \\
SSTR5 N
\end{tabular}

$\begin{array}{r}\hline \multicolumn{1}{c}{\mathbf{P C}} \\ \hline 13 / 32 \\ 17 / 32 \\ 7 / 32 \\ 2 / 32 \\ 9 / 32 \\ 9 / 32 \\ 2 / 32 \\ 18 / 32 \\ 20 / 32 \\ 1 / 32 \\ 28 / 32 \\ 30 / 32 \\ \hline\end{array}$

\begin{tabular}{c}
\hline APA \\
\hline $9 / 27$ \\
$18 / 27$ \\
$5 / 27$ \\
0 \\
$7 / 27$ \\
$6 / 27$ \\
0 \\
$11 / 27$ \\
$14 / 27$ \\
$1 / 27$ \\
$15 / 27$ \\
$20 / 27$ \\
\hline
\end{tabular}

\begin{tabular}{c}
\hline PA \\
\hline $30 / 72$ \\
$50 / 72$ \\
$3 / 72$ \\
0 \\
$11 / 72$ \\
$2 / 72$ \\
0 \\
$21 / 72$ \\
$23 / 72$ \\
$4 / 72$ \\
$11 / 72$ \\
$50 / 72$ \\
\hline
\end{tabular}

\begin{tabular}{c}
\hline P value \\
\hline 0.512 \\
0.269 \\
$0.01^{a}$ \\
0.264 \\
$<0.001^{a}$ \\
$0.032^{a}$ \\
$0.009^{a}$ \\
0.873 \\
$<0.001^{a}$ \\
$0.038^{a}$ \\
\hline
\end{tabular}

asignificant $P$ values.

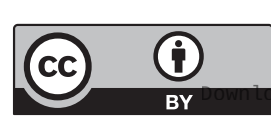

This work is licensed under a Creative Commons Attribution 4.0 International License. 
Table 4 SSTR expression for all tumor groups in relation to Ki-67, tumor size, s-Ca-ion and s-PTH expressed as median (range).

\begin{tabular}{|c|c|c|c|}
\hline & \multicolumn{3}{|c|}{ SSTR2C } \\
\hline & Positive tumors & Negative tumors & $P$ value \\
\hline Ki-67 (\%) & $5.8(0-30)$ & $3.1(0-40)$ & 0.069 \\
\hline Tumor size (cm) & $2.48(1.0-4.0)$ & $2.0(1.0-5.0)$ & 0.142 \\
\hline S-Ca-ion (mmol/L) & $1.69(1.38-2.42)$ & $1.56(1.28-2.58)$ & 0.098 \\
\hline \multirow[t]{3}{*}{ S-PTH (ng/l) } & 727 (34-2001) & $514(68-4000)$ & 0.198 \\
\hline & \multicolumn{3}{|c|}{ SSTR3N } \\
\hline & Positive tumors & Negative tumors & $P$ value \\
\hline Ki-67 & $5.6(0-20)$ & $3.1(0-40)$ & $0.003^{a}$ \\
\hline Tumor size (cm) & $2.54(1.0-4.0)$ & $2.0(1-5)$ & 0.09 \\
\hline S-Ca-ion (mmol/L) & $1.63(1.32-2.02)$ & $1.56(1.28-2.58)$ & 0.107 \\
\hline \multirow[t]{3}{*}{ S-PTH (ng/L) } & 1049 (147-2769) & $461(34-4000)$ & $0.003^{a}$ \\
\hline & \multicolumn{3}{|c|}{ SSTR4C } \\
\hline & Positive tumors & Negative tumors & $P$ value \\
\hline Ki-67 & $4.1(0-40)$ & $3.1(0-40)$ & $0.048^{\mathrm{a}}$ \\
\hline Tumor size (cm) & $2.2(1.0-5.0)$ & $2.0(1.0-5.0)$ & 0.607 \\
\hline S-Ca-ion (mmol/L) & $1.60(1.29-2.58)$ & $1.55(128-2.42)$ & 0.142 \\
\hline \multirow[t]{3}{*}{ S-PTH (ng/L) } & $613(68-4000)$ & 485 (34-2220) & 0.139 \\
\hline & \multicolumn{3}{|c|}{ SSTR4N } \\
\hline & Positive tumors & Negative tumors & $P$ value \\
\hline Ki-67 & $4.1(0.40)$ & $3.0(0-30)$ & 0.225 \\
\hline Tumor size (cm) & $2.23(1-5)$ & $2.0(1.0-4.0)$ & 0.825 \\
\hline S-Ca-ion (mmol/L) & $1.57(1.29-2.04)$ & $1.58(128-2.58)$ & 0.487 \\
\hline \multirow[t]{3}{*}{ S-PTH (ng/L) } & $580(34-2220)$ & $500(68-4000)$ & 0.258 \\
\hline & \multicolumn{3}{|c|}{ SSTR5C } \\
\hline & Positive tumors & Negative tumors & $P$ value \\
\hline Ki-67 & $4.0(0-40)$ & $1.4(0-30)$ & $<0.001^{a}$ \\
\hline Tumor size (cm) & $2.20(1.0-5.0)$ & $2.0(1.0-5.0)$ & 0.135 \\
\hline S-Ca-ion (mmol/L) & $1.68(1.32-2.58)$ & $1.45(1.28-2.42)$ & $<0.001^{\mathrm{a}}$ \\
\hline \multirow[t]{3}{*}{ S-PTH (ng/L) } & 634 (34-4000) & 173 (73-2210) & $<0.001^{a}$ \\
\hline & \multicolumn{3}{|c|}{ SSTR5N } \\
\hline & Positive tumors & Negative tumors & $P$ value \\
\hline Ki-67 & $0.0(0-40)$ & $0.0(0-10)$ & 0.267 \\
\hline Tumor size (cm) & $2.0(1.0-5.0)$ & $2.0(1.0-4.0)$ & 0.079 \\
\hline S-Ca-ion (mmol/L) & $1.52(1.28-2.58)$ & $1.45(1.29-1.85)$ & 0.141 \\
\hline S-PTH(ng/L) & $264(34-4000)$ & 188 (77-2220) & 0.230 \\
\hline
\end{tabular}

aSignificant $P$ values.

and another had metastatic disease. The third presented with non-recurrent disease. The median circulating PTH concentrations (1187ng/L vs $823 \mathrm{ng} / \mathrm{L})$ and Ki-67 (13 vs $7 \%$ ) were higher in $\mathrm{SST}_{5} \mathrm{C}$-negative PCs compared to $\mathrm{SST}_{5} \mathrm{C}$-positive tumors, although this difference was not statistically significant (Mann-Whitney $U$ ).

We also examined membrane-positive tumors for $\mathrm{SST}_{2}$ and $\mathrm{SST}_{3}$ separately. One $\mathrm{SST}_{3} \mathrm{M}$-positive PC patient died of disease. The other $\mathrm{SST}_{3} \mathrm{M}$-positive tumor appeared $\mathrm{SST}_{5} \mathrm{C}$-negative but was otherwise unremarkable. In addition, one $\mathrm{SST}_{2} \mathrm{M}$-positive PC patient was also $\mathrm{SST}_{5} \mathrm{C}$ negative and died from the disease. The $\mathrm{SST}_{2} \mathrm{M}$-positive tumor patients exhibited a slightly higher serum ionized calcium concentration than the remainder of the group (median $2.09 \mathrm{mg} / \mathrm{L}$ compared to $1.75 \mathrm{mg} / \mathrm{L}$ ). The $\mathrm{SST}_{2} \mathrm{M}$ positive tumor patients were also characterized by higher Ki-67 ( 2 vs 5\%). All differences between SST $_{2} \mathrm{M}$-positive tumors and the remainder of the PC group were not statistically significant.

\section{Discussion}

Here, we demonstrate that SSTs 1 through 5 are expressed in different parathyroid tumors, while $\mathrm{SST}_{5}$ is particularly abundant in PCs. Furthermore, we show that $\mathrm{SST}_{5}$ expression correlates with the tumor Ki-67 proliferation index, as well as with the circulating calcium and PTH 
Table 5 Expression of $\mathrm{SST}_{5} \mathrm{C}, \mathrm{SST}_{3} \mathrm{M}$ and $\mathrm{SST}_{2} \mathrm{M}$ in relation to disease aggressiveness in $\mathrm{PC}$.

\begin{tabular}{|c|c|c|c|}
\hline & \multicolumn{3}{|c|}{ SST expression (number of tumors) } \\
\hline & $\mathrm{SST}_{5} \mathrm{C}$ & $\mathrm{SST}_{3} \mathrm{M}$ & $\mathrm{SST}_{2} \mathrm{M}$ \\
\hline Patients with recurrent/metastatic disease $(n=7)$ & $5 / 7$ & $1 / 7$ & $1 / 7$ \\
\hline Patients died from disease (also included in recurrent/metastatic, $n=5$ ) & $4 / 5$ & $1 / 5$ & $1 / 5$ \\
\hline Patients with non-recurrent disease $(n=25)$ & $23 / 25$ & $1 / 25$ & $1 / 25$ \\
\hline
\end{tabular}

concentrations. In addition, the expression of cytoplasmic $\mathrm{SST}_{2}, \mathrm{SST}_{4}$ and $\mathrm{SST}_{5}$ as well as nuclear $\mathrm{SST}_{3}, \mathrm{SST}_{4}$ and $\mathrm{SST}_{5}$ consistently mirror the lowest expressions in adenomas, the intermediate expression in atypical adenomas and the highest expression in carcinomas. While membrane positivity is very seldom detectable, four PCs showed membrane positivity either for $\mathrm{SST}_{2}$ or $\mathrm{SST}_{3}$, suggesting that $\mathrm{SST}_{2}$ - and $\mathrm{SST}_{3}$-targeted imaging and therapies could potentially improve the management of these patients.

Taniyama et al. demonstrated the expression of $\mathrm{SST}_{1}, \mathrm{SST}_{3}$ and $\mathrm{SST}_{4}$ (and to some degree $\mathrm{SST}_{5}$ ) expression in chief cells of normal parathyroid tissue using immunohistochemistry relying on polyclonal antibodies (22). We used monoclonal antibodies, demonstrating scarce expression of $\mathrm{SST}_{5}$ in normal parathyroid cells; but, in contrast to Taniyama et al., we could not detect the expression of $\mathrm{SST}_{1}, \mathrm{SST}_{3}$ or $\mathrm{SST}_{4}$ in normal parathyroid tissue. To our knowledge, our study represents the first on SST expression in neoplastic parathyroid tissue. SST expression was lowest in adenomas and highest in carcinomas, with atypical adenomas falling in between. Negative SST stainings for normal parathyroid tissue fit with the pattern of an increased SST expression and an increasing neoplasticity.

The expression of somatostatin receptors carries a prognostic role in other neuroendocrine tumors. In gastroenteropancreatic NETs (GEP-NETs), SSTs are generally overexpressed in well-differentiated tumors with a decreasing expression in dedifferentiated tumors (29). In GEP-NETs, $\mathrm{SST}_{2}$ is the most frequently expressed receptor (30). The presence of $\mathrm{SST}_{5}$ and the absence of $\mathrm{SST}_{2}$ correlate with metastasis, angioinvasion and tumor growth (31). In pancreatic NETs, the low expression of $\mathrm{SST}_{2}$ and $\mathrm{SST}_{5}$ associates with a worse disease prognosis (32). When analyzing the PC group exclusively, we found that $\mathrm{SST}_{5} \mathrm{C}$-negative carcinomas appeared to have higher calcium and PTH levels than the entire PC group average. These parameters previously investigated in our cohort strongly correlated with the nature of the tumor. Thus, the association between these parameters and SST expression is biased given that all these factors correlate with malignancy (8). Furthermore, the number of PCs with an adverse outcome is small.
The antibodies used in our study have been previously used and verified $(25,26,27,28,33)$ with Western blotting and/or in vitro somatostatin receptor autoradiography. The same antibodies have previously been used by our research group for a study on pulmonary carcinoid tumors (23) as well as pheochromocytomas and paragangliomas (antibodies for $\mathrm{SST}_{2}-\mathrm{SST}_{4}$ (34)). We stained control tissue (pancreas and small intestine) to serve as a test for the functionality of the staining protocol as well as internal negative control. The Langerhans' islet cells and enteroendocrine cells stained positive appropriate to the SST antibody used, while the surrounding tissue remained negative. Thus, one can assume that the staining we have observed is, in fact, valid also regarding the nuclear expression of SSTs.

In general, somatostatin receptors are considered membrane-bound G-protein-coupled receptors (35), with some degree of cytoplasmic staining on immunohistochemistry. We found that the membrane expression ofSSTswereboth faintandscarce.Ligandbinding to somatostatin receptors induces receptor internalization by endocytosis for the lysosomal regrading or recycling of the receptor to the plasma membrane $(36,37)$. This could represent one mechanism explaining the cytoplasmic SST staining. Previous studies indicate that antibodies for $\mathrm{SST}_{2}$ generally stain the plasma membrane, while $\mathrm{SST}_{1}$, $\mathrm{SST}_{3}$ and $\mathrm{SST}_{5}$ stain the cytoplasm (38). Furthermore, SST expression generally decreases with a higher tumor grade as demonstrated in different NETs including pituitary adenomas, GEP-NETs, pheochromocytomas and paragangliomas, neuroblastoma, Merkel cell carcinoma and medullary thyroid carcinoma (38). Most previous studies have focused on membrane expression. We recently demonstrated that in pheochromocytomas and paragangliomas $\mathrm{SST}_{1-5}$ expression is either predominantly membranous ( $\left.\mathrm{SST}_{2}\right)$ or cytoplasmic $\left(\mathrm{SST}_{1}, 3_{3-5}\right)(34)$. In the present study, nuclear and cytoplasmic SST expression appeared in the majority of parathyroid tumors, with significantly different expression profiles in adenomas, atypical adenomas and carcinomas. The nuclear expression of somatostatin receptors is scarcely described in the literature and the significance of this observation remains unclear. Perhaps a publication bias has

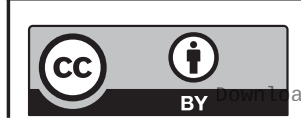

This work is licensed under a Creative Commons Attribution 4.0 International License. ded from Bioscientifica.com at 04/26/2023 05:02:46AM 
affected this finding. Previously, Hornick et al. described a radioactive-labeled somatostatin analog uptake in the cell nucleus of human neuroblastoma cells (39). Some researchers have speculated that the antiproliferative and apoptotic properties of somatostatin are mediated through the protein $86-\mathrm{Ku}$, which has been shown to function as a somatostatin receptor. Binding of somatostatin to $86-\mathrm{Ku}$ promotes the translocation of $86-\mathrm{Ku}$ from the cytoplasm to the nucleus $(40,41)$. It is possible, however speculative, that the nuclear SST expression described here represents a cross-reaction between SST antibodies and 86-Ku.

No standardized scoring system for the immunohistochemical evaluation of SSTs currently exists. The scoring system used by Körner et al. (42) (examining $\mathrm{SST}_{2}$, in particular) yielded a strong correlation with the binding of the somatostatin receptor measured using in vitro receptor autoradiography. This was, however, primarily focused on membrane expression, which was marginally prevalent in our tumor samples. Specht et al. compared three different scoring systems on the SST expression in bronchopulmonary neoplasms: the immunoreactive score (IRS) originally developed for the evaluation of estrogen and progesterone receptors in breast cancer, the Her2/neu score developed for the evaluation of HER expression in breast cancer and the hormone receptor score (H score). These scoring systems were compared to the results obtained using real-time PCR, whereby all showed some correlation, although the IRS scoring system emerged with the strongest correlation to the RT-PCR results (43). All of these scoring systems rely on the percentage of stained cells in combination with the staining intensity. In our study, the intensity of the stained spots was generally weak and the percentage of stained cells was low, particularly regarding the nuclear expression. Analyses using either a higher cut-off point (counting weakly positive spots scored 1 as negative) or a minimum of $10 \%$ stained cells for positivity yielded insignificant results and the number of positive tumors decreased considerably. A cut-off point of $10 \%$ to be considered positive has been suggested for staining of $\mathrm{SST}_{2}$ (25); however, there is no consensus on the matter, as also a small number of receptor-positive tumor cells might be biologically and/or clinically relevant (42). A cut-off point as low as $1 \%$ has been used regarding other markers, such as PDL-1 (44). The actual or clinical significance of the weakly stained spots can be questioned. A higher staining dilution might further weed out false-positive spots. While the PPV for cytoplasmic SST S $_{5}$ is only 0.52 , slightly better than chance, the NPV is 0.94. According to Juhlin et al., the NPV of negative parafibromin staining is also around this magnitude (18). This suggests that a negative staining for cytoplasmic $\mathrm{SST}_{5}$ strongly indicates a benign tumor.

In general, SSTs represent potential targets for imaging and the treatment of NETs. Occasional case studies indicate that octreotide might affect PTH-associated hypercalcemia and reduce the urinary calcium output in primary hyperparathyroidism (45). For instance, Karacavus et al. published a case report of a $\mathrm{SST}_{1}$-positive parathyroid adenoma discovered on an octreotide scintigraphy (46). Long-acting octreotide has been proposed as a possible treatment for PHPT due to adenoma in MEN1 patients. Furthermore, somatostatin analogs have been tested in the treatment of hyperparathyroidism alongside surgery without an apparent effect on the patients' serum calcium or PTH levels $(20,47,48)$. Because PCs are so rare, parathyroid adenomas have primarily been used in these studies.

Among all SSTs, SST $_{2}$ stands as the most commonly expressed throughout the body. In clinical settings, the most commonly used somatostatin analogs, such as octreotide and lanreotide, target $\mathrm{SST}_{2}$ in particular, and also share a certain affinity with $\mathrm{SST}_{5}$. Newer somatostatin analogs such as pasireotide and somatoprim have affinity for all receptor subtypes, although $\mathrm{SST}_{4}$ to a lesser extent (20). Presumably, membranous expression stands as a prerequisite for successful treatment or for imaging using octreotide or other somatostatin analogs. In our study, membrane expression was scarce and did not significantly differ between the tumor groups. However, the two $\mathrm{SST}_{2}$ and $\mathrm{SST}_{3}$ membrane-positive tumors were malignant; and we were particularly interested in these receptors due to the clinical significance of membrane positivity. We found that among the five patients who died of PC-related causes, one was $\operatorname{SST}_{2} \mathrm{M}$ positive and another was $\mathrm{SST}_{3} \mathrm{M}$ positive, indicating that these tumors might be more aggressive than their negative counterparts. New treatment options could have proved useful in these cases. Moreover, further research is necessary in order to conclude whether somatostatin analogs targeting these receptors could be used to treat membranous SSTpositive PC tumors. In patients with metastatic disease not responding to conventional treatment, it may be possible to examine the expression of $\mathrm{SST}_{2} \mathrm{M}$ and $\mathrm{SST}_{3} \mathrm{M}$ for individually customized targeted treatment using somatostatin analogs.

PC is one of the rarest carcinomas known, making it difficult to study and treat. We studied a nationwide cohort $(n=32)$. The number of carcinomas studied was relatively small and our findings warrant validation in other cohorts. TMAs are not considered representative

This work is licensed under a Creative Commons Attribution 4.0 International License. ded from Bioscientifica,com at 04/26/2023 05:02:46AM 
of the tissue as a whole. This was taken into account by taking several punches from each tumor, both from the middle and from the borders of the tumors. Our results are consistent, and our statistically significant findings follow a gradient with the highest SST expression in PCs without exception.

\section{Conclusions}

Using immunohistochemistry, we demonstrate that SST $_{1-5}$ are expressed in parathyroid tumors, either in the cytoplasm or the nucleus. The expression profiles of $\mathrm{SST}_{2-5}$ differ significantly between benign, atypical and malignant parathyroid tumors. Additionally, due to the large differences in expression between the tumor groups, $\mathrm{SST}_{5}$ represents a potential new immunohistochemistry panel marker for PC in addition to the established markers parafibromin and Ki-67 and suggested markers galectin 3 and PGP9.5.

\section{Declaration of interest}

The authors declare that there is no conflict of interest that could be perceived as prejudicing the impartiality of the research reported.

\section{Funding}

This work was financially supported by the Helsinki University Hospital Research Funds (TYH2017204, TYH2017138 and TYH2018223) and Finska Läkaresällskapet (to C Schalin-Jäntti).

\section{Author contribution statement}

Study design: J A, C S J and C H. Study conduct: S S, H L, E R and J A. Literature review: S S, J A, C S J. Data collection: S S and E R. Statistical analysis: J L and S S. Drafting manuscript: S S, J A and C S J. Revising manuscript content: $S S, H L, E R, J L, C H, C S$ J and J A. Approving final version: S S, H L, E R, J L, $\mathrm{CH}, \mathrm{CS}$ J and $\mathrm{A}$.

\section{Acknowledgments}

The authors thank Eija Heiliö, Päivi Peltokangas and Tiina Vesterinen for their excellent technical assistance. They also thank colleagues from the university and central hospitals who helped gather the tumor samples and patient data.

\section{References}

1 Talat N \& Schulte KM. Clinical presentation, staging and long-term evolution of parathyroid cancer. Annals of Surgical Oncology 201017 2156-2174. (https://doi.org/10.1245/s10434-010-1003-6)

2 Cetani F, Pardi E \& Marcocci C. Update on parathyroid carcinoma. Journal of Endocrinological Investigation 201639 595-606. (https://doi org/10.1007/s40618-016-0447-3)

3 Goswamy J, Lei M \& Simo R. Parathyroid carcinoma. Current Opinion in Otolaryngology and Head and Neck Surgery 201624 155-162. (https://doi.org/10.1097/MOO.0000000000000234)
4 Storvall S, Ryhänen EM, Bensch FV, Heiskanen I, Kytölä S, Ebeling T, Mäkelä S \& Schalin-Jäntti C. Recurrent metastasized parathyroid carcinoma - long-term remission after combined treatments with surgery, radiotherapy, Cinacalcet, zoledronic acid and temozolomide. JBMR Plus 20182 1-6. (https://doi.org/10.1002/jbm4.10114)

5 Villar-del-Moral J, Jiménez-García A, Salvador-Egea P, MartosMartínez JM, Nuño-Vázquez-Garza JM, Serradilla-Martín M, Gómez-Palacios A, Moreno-Llorente P, Ortega-Serrano J \& de la Quintana-Basarrate A. Prognostic factors and staging systems in parathyroid cancer: a multicenter cohort study. Surgery 2014156 1132-1144. (https://doi.org/10.1016/j.surg.2014.05.014)

6 Asare EA, Sturgeon C, Winchester DJ, Liu L, Palis B, Perrier ND, Evans DB, Winchester DP \& Wang TS. Parathyroid carcinoma: an update on treatment outcomes and prognostic factors from the national cancer data base (NCDB). Annals of Surgical Oncology 2015 22 3990-3995. (https://doi.org/10.1245/s10434-015-4672-3.

7 Harari A, Waring A, Fernandez-Ranvier G, Hwang J, Suh I, Mitmaker E, Shen W, Gosnell J, Duh QY \& Clark O, et al. Parathyroid carcinoma: A 43-year outcome and survival analysis. Journal of Clinical Endocrinology and Metabolism 201196 3679-3686. (https:// doi.org/10.1210/jc.2011-1571)

8 Ryhänen EM, Leijon H, Metso S, Eloranta E, Korsoff P, Ahtiainen P, Kekäläinen $\mathrm{P}$, Tamminen M, Ristamäki R, Knutar O, et al. A nationwide study on parathyroid carcinoma. Acta Oncologica 201756 991-1003. (https://doi.org/10.1080/0284186X.2017.1306103)

9 Lee PK, Jarosek SL, Virnig BA, Evasovich M \& Tuttle TM. Trends in the incidence and treatment of parathyroid cancer in the United States. Cancer 2007109 1736-1741. (https://doi.org/10.1002/ cncr.22599)

10 Brown S, O’Neill C, Suliburk J, Sidhu S, Sywak M, Gill A, Robinson B \& Delbridge L. Parathyroid carcinoma: increasing incidence and changing presentation. ANZ Journal of Surgery $2011 \mathbf{8 1} 528-532$. (https://doi.org/10.1111/j.1445-2197.2010.05594.x)

11 Duan K, Hernandez KG \& Mete O. Clinicopathological correlates of hyperparathyroidism. Journal of Clinical Pathology 201568 771-787. (https://doi.org/10.1136/jclinpath-2015-203186)

12 Quinn CE, Healy J, Lebastchi AH, Brown TC, Stein JE, Prasad ML, Callender GG, Carling T \& Udelsman R. Modern experience with aggressive parathyroid tumors in a high-volume new England referral center. Journal of the American College of Surgeons 20152201054 1062. (https://doi.org/10.1016/j.jamcollsurg.2014.10.007)

13 Kim HK, Oh YL, Kim SH, Lee DY, Kang HC, Lee JI, Jang HW, Hur KY, Kim JH, Min YK, et al. Parafibromin immunohistochemical staining to differentiate parathyroid carcinoma from parathyroid adenoma. Head and Neck 201234 201-206. (https://doi.org/10.1002/ hed.21716)

14 Cetani F, Banti C, Pardi E, Borsari S, Viacava P, Miccoli P, Torregrossa L, Basolo F, Pelizzo MR, Rugge M, et al. CDC73 mutational status and loss of parafibromin in the outcome of parathyroid cancer. Endocrine Connections 20132 186-195. (https:// doi.org/10.1530/EC-13-0046)

15 Bollerslev J, Schalin-Jantti C, Rejnmark L, Siggelkow H, Morreau H, Thakker RV, Sitges-Serra A, Cetani F \& Marcocci C. MANAGEMENT OF ENDOCRINE DISEASE: Unmet therapeutic, educational and scientific needs in parathyroid disorders. European Journal of Endocrinology 2019181 P1-P19. (https://doi.org/10.1530/EJE-190316)

16 Gill AJ, Lim G, Cheung VKY, Andrici J, Perry-Keene JL, Paik J, Sioson L, Clarkson A, Sheen A, Luxford C, et al. Parafibromindeficient (HPT-JT Type, CDC73 mutated) parathyroid tumors demonstrate distinctive morphologic features. American Journal of Surgical Pathology 201943 35-46. (https://doi.org/10.1097/ PAS.0000000000001017)

17 van der Tuin K, Tops CMJ, Adank MA, Cobben JM, Hamdy NAT, Jongmans MC, Menko FH, van Nesselrooij BPM, Netea-Maier RT \& Oosterwijk JC. CDC73-related disorders: clinical manifestations and

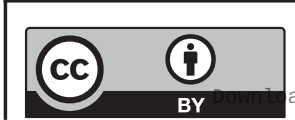

This work is licensed under a Creative Commons Attribution 4.0 International License. ded from Bioscientifica.com at 04/26/2023 05:02:46AM 
case detection in primary hyperparathyroidism. Journal of Clinical Endocrinology and Metabolism 2017102 4534-4540. (https://doi. org/10.1210/jc.2017-01249)

18 Juhlin CC, Nilsson IL, Lagerstedt-Robinson K, Stenman A, Bränström R, Tham E \& Höög A. Parafibromin immunostainings of parathyroid tumors in clinical routine: a near-decade experience from a tertiary center. Modern Pathology 201932 1082-1094. (https:// doi.org/10.1038/s41379-019-0252-6)

19 Theodoropoulou M \& Stalla GK. Frontiers in Neuroendocrinology somatostatin receptors: from signaling to clinical practice. Frontier in Neuroendocrinology 201334 228-252. (https://doi.org/10.1016/j. yfrne.2013.07.005)

20 Barbieri F, Bajetto A, Pattarozzi A, Gatti M, Würth R, Thellung S, Corsaro A, Villa V, Nizzari M \& Florio T. Peptide receptor targeting in cancer: the somatostatin paradigm. International Journal of Peptides 20132013 926295. (https://doi.org/10.1155/2013/926295)

21 Kamp K, Feelders RA, van Adrichem RC, de Rijke YB, van Nederveen FH, Kwekkeboom DJ \& de Herder WW. Parathyroid hormone-related peptide (PTHrP) secretion by gastroenteropancreatic neuroendocrine tumors (GEP-NETs): clinical features, diagnosis, management, and follow-up. Journal of Clinical Endocrinology and Metabolism 201499 3060-3069. (https://doi.org/10.1210/jc.20141315)

22 Taniyama Y, Suzuki T, Mikami Y, Moriya T, Satomi S \& Sasano H. Systemic distribution of somatostatin receptor subtypes in human: an immunohistochemical study. Endocrine Journal 200552 605-611. (https://doi.org/10.1507/endocrj.52.605)

23 Vesterinen T, Leijon H, Mustonen H, Remes S, Knuuttila A, Salmenkivi K, Vainio P, Arola J \& Haglund C. Somatostatin receptor expression is associated with metastasis and patient outcome in pulmonary carcinoid tumors. Journal of Clinical Endocrinology and Metabolism 2019104 2083-2093. (https://doi.org/10.1210/jc.201801931)

24 Fischer T, Doll C, Jacobs S, Kolodziej A, Stumm R \& Schulz S. Reassessment of sst2 somatostatin receptor expression in human normal and neoplastic tissues using the novel rabbit monoclonal antibody UMB-1. Journal of Clinical Endocrinology and Metabolism 200893 4519-4524. (https://doi.org/10.1210/jc.2008-1063)

25 Körner M, Waser B, Schonbrunn A, Perren A \& Reubi JC. Somatostatin receptor subtype $2 \mathrm{~A}$ immunohistochemistry using a new monoclonal antibody selects tumors suitable for in vivo somatostatin receptor targeting. American Journal of Surgical Pathology 201236 242-252. (https://doi.org/10.1097/ PAS.0b013e31823d07f3)

26 Lupp A, Nagel F, Doll C, Rocken C, Evert M, Mawrin C, Saeger W \& Schulz S. Reassessment of sst3 somatostatin receptor expression in human normal and neoplastic tissues using the novel rabbit monoclonal antibody UMB-5. Neuroendocrinology 201296 301-310. (https://doi.org/10.1159/000337659)

27 Lupp A, Hunder A, Petrich A, Nagel F, Doll C \& Schulz S. Reassessment of sst(5) somatostatin receptor expression in normal and neoplastic human tissues using the novel rabbit monoclonal antibody UMB-4. Neuroendocrinology 201194 255-264. (https://doi. org/10.1159/000329876)

28 Lupp A, Nagel F \& Schulz S. Reevaluation of sst $_{1}$ somatostatin receptor expression in human normal and neoplastic tissues using the novel rabbit monoclonal antibody UMB-7. Regulatory Peptides 2013183 1-6. (https://doi.org/10.1016/j.regpep.2013.02.001)

29 Modlin IM, Pavel M, Kidd M \& Gustafsson BI. Review article: somatostatin analogues in the treatment of gastroenteropancreatic neuroendocrine (carcinoid) tumours. Alimentary Pharmacology and Therapeutics 201031 169-188. (https://doi.org/10.1111/j.13652036.2009.04174.x)

30 Reubi JC. Somatostatin and other peptide receptors as tools for tumor diagnosis and treatment. Neuroendocrinology $2004 \mathbf{8 0}$ (Supplement 1) 51-56. (https://doi.org/10.1159/000080742)
31 Berardi R, Morgese F, Torniai M, Savini A, Partelli S, Rinaldi S, Caramanti M, Ferrini C, Falconi M \& Cascinu S. Medical treatment for gastro-entero-pancreatic neuroendocrine tumours. World Journal of Gastrointestinal Oncology 20168 389-401. (https://doi.org/10.4251/ wjgo.v8.i4.389)

32 Mehta S, de Reuver PR, Gill P, Andrici J, D’Urso L, Mittal A, Pavlakis N, Clarke S, Samra JS \& Gill AJ. Somatostatin receptor SST-2a expression is a stronger predictor for survival than Ki-67 in pancreatic neuroendocrine tumors. Medicine 201594 e1281. (https:// doi.org/10.1097/MD.0000000000001281)

33 Schmid HA, Lambertini C, van Vugt HH, Barzaghi-Rinaudo P, Schäfer J, Hillenbrand R, Sailer AW, Kaufmann M \& Nuciforo P. Monoclonal antibodies against the human somatostatin receptor subtypes 1-5: development and immunohistochemical application in neuroendocrine tumors. Neuroendocrinology 201295 232-247. (https://doi.org/10.1159/000330616)

34 Leijon H, Remes S, Hagström J, Louhimo J, Mäenpää H, SchalinJäntti C, Miettinen M, Haglund C \& Arola J. Variable somatostatin receptor subtype expression in 151 primary pheochromocytomas and paragangliomas. Human Pathology 201986 66-75. (https://doi. org/10.1016/j.humpath.2018.11.020)

35 Volante M, Rosas R, Allìa E, Granata R, Baragli A, Muccioli G \& Papotti M. Somatostatin, cortistatin and their receptors in tumours. Molecular and Cellular Endocrinology 2008286 219-229. (https://doi. org/10.1016/j.mce.2007.12.002)

36 Jacobs S \& Schulz S. Intracellular trafficking of somatostatin receptors. Molecular and Cellular Endocrinology 2008286 58-62. (https://doi.org/10.1016/j.mce.2007.10.005)

37 Csaba Z, Peineau S \& Dournaud P. Molecular mechanisms of somatostatin receptor trafficking. Journal of Molecular Endocrinology 201225 R1-R12. (https://doi.org/10.1530/JME-11-0121)

38 Hankus J \& Tomaszewska R. Neuroendocrine neoplasms and somatostatin receptor subtypes expression. Nuclear Medicine Review: Central and Eastern Europe 201619 111-117. (https://doi. org/10.5603/NMR.2016.0022)

39 Hornick CA, Anthony CT, Hughey S, Gebhardt BM, Espenan GD \& Woltering EA. Progressive nuclear translocation of somatostatin analogs. Journal of Nuclear Medicine 200041 1256-1263.

40 Le Romancer M, Reyl-Desmars F, Cherifi Y, Pigeon C, Bottari S, Meyer O \& Lewin MJ. The $86-\mathrm{kDa}$ subunit of autoantigen $\mathrm{Ku}$ is a somatostatin receptor regulating protein phosphatase-2A activity. Journal of Biological Chemistry 1994269 17464-17468.

41 Tóvári J, Szende B, Bocsi J, Falaschi A, Simoncsits A, Pongor S, Erchegyi J, Steták A \& Kéri G. A somatostatin analogue induces translocation of $\mathrm{Ku} 86$ autoantigen from the cytosol to the nucleus in colon tumour cells. Cellular Signalling 199810 277-282. (https:// doi.org/10.1016/S0898-6568(97)00128-9)

42 Körner M, Waser B, Christ E, Beck J \& Reubi JC. A critical evaluation of sst3 and sst5 immunohistochemistry in human pituitary adenomas. Neuroendocrinology 2018106 116-127. (https://doi. org/10.1159/000472563)

43 Specht E, Kaemmerer D, Sänger J, Wirtz RM, Schulz S \& Lupp A. Comparison of immunoreactive score, HER2/neu score and $\mathrm{H}$ score for the immunohistochemical evaluation of somatostatin receptors in bronchopulmonary neuroendocrine neoplasms. Histopathology 201567 368-377. (https://doi.org/10.1111/his.12662)

44 Kim H, Kwon HJ, Park SY, Park Y, Park E \& Chung JH. Clinicopathological analysis and prognostic significance of programmed cell death-ligand 1 protein and mRNA expression in non-small cell lung cancer. PLOS ONE 201813 e0198634. (https:// doi.org/10.1371/journal.pone.0198634)

45 Lucarotti ME, Hamilton JA \& Farndon JR. Somatostatin and primary hyperparathyroidism. British Journal of Surgery 199481 1141-1143. (https://doi.org/10.1002/bjs.1800810819)

46 Karaçavuş S, Kula M, Cihan Karaca Z, Unlühızarcı K, Tutuş A, Bayram F \& Coban G. Octreotide uptake in parathyroid adenoma.

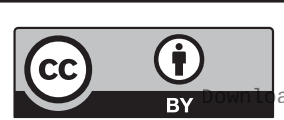

This work is licensed under a Creative Commons Attribution 4.0 International License. 
Molecular Imaging and Radionuclide Therapy 201221 77-79. (https:// doi.org/10.4274/Mirt.4)

47 Faggiano A, Tavares LB, Tauchmanova L, Milone F, Mansueto G, Ramundo V, De Caro ML, Lombardi G, De Rosa G \& Colao A. Effect of treatment with depot somatostatin analogue octreotide on primary hyperparathyroidism (PHP) in multiple endocrine neoplasia type 1 (MEN1) patients. Clinical Endocrinology 200869 756-762. (https://doi.org/10.1111/j.1365-2265.2008.03301.x)

48 Zielke A, Hasse C, Bruns C, Sitter H \& Rothmund M. Octreotide: effective treatment for hyperparathyroidism? A prospective, randomized, controlled clinical trial. Surgery 1997121 606-610. (https://doi.org/10.1016/S0039-6060(97)90047-7)

Received in final form 17 July 2019

Accepted 23 July 2019

Accepted Preprint published online 23 July 2019

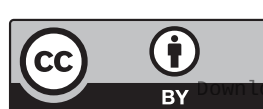

This work is licensed under a Creative Commons Attribution 4.0 International License.

ded from Bioscientifica.com at 04/26/2023 05:02:46AM via free access 